\title{
Assessing seabird bycatch in gillnet fisheries using electronic monitoring
}

\author{
Glemarec, Gildas; Kindt-Larsen, Lotte; Lundgaard, Louise Scherffenberg; Larsen, Finn
}

Published in:

Biological Conservation

Link to article, DOI:

10.1016/j.biocon.2020.108461

Publication date:

2020

Document Version

Peer reviewed version

Link back to DTU Orbit

Citation (APA):

Glemarec, G., Kindt-Larsen, L., Lundgaard, L. S., \& Larsen, F. (2020). Assessing seabird bycatch in gillnet fisheries using electronic monitoring. Biological Conservation, 243, [108461].

https://doi.org/10.1016/j.biocon.2020.108461

\section{General rights}

Copyright and moral rights for the publications made accessible in the public portal are retained by the authors and/or other copyright owners and it is a condition of accessing publications that users recognise and abide by the legal requirements associated with these rights.

- Users may download and print one copy of any publication from the public portal for the purpose of private study or research.

- You may not further distribute the material or use it for any profit-making activity or commercial gain

- You may freely distribute the URL identifying the publication in the public portal

If you believe that this document breaches copyright please contact us providing details, and we will remove access to the work immediately and investigate your claim. 
Gildas Glemarec, Lotte Kindt-Larsen, Louise Scherffenberg Lundgaard, Finn Larsen

\section{Abstract}

Keywords: Electronic monitoring, Seabirds, Bycatch, Gillnets, Fisheries interaction

Running head: Electronic monitoring of seabird bycatch

\section{Introduction}

Unintentional captures in fishing gears (or bycatch) are a major cause of mortality for air-breathing marine animals like seabirds, sea turtles, or cetaceans (Tasker et al., 2000; Lewison et al., 2014; Northridge et al., 2017). In particular, entanglement in gillnets is responsible for the drowning of hundreds of thousands of seabirds each year (Žydelis et al., 2013), and has been identified as a major threat for some vulnerable populations (Žydelis et al., 2009; Croxall et al., 2012; Dias et al., 2019). In the European Union, despite the commitments of the Member States to protect and conserve avifauna (EU, 2009), and although a strong legislative body is in place to guarantee no or minimal bycatch of sensitive species (through the Common Fisheries Policy and the Marine Strategy Framework Directive notably), seabird bycatch remains an unresolved problem. In 2012, the European Commission established an "Action Plan for reducing incidental catches of seabirds in fishing gears" (EC, 2012), calling upon Member States to estimate the impact of their national fisheries on seabirds, and to come up with effective methods to reduce or suppress incidental catches. However, in most European countries, bycatch data collection relies upon non-dedicated programmes conducted under the Data Collection Framework (DCF). Only few dedicated bycatch sampling programmes exist, usually limited in time and space (ICES, 2018), with the noteworthy exception of the long-term protected species bycatch monitoring programme (PSBMP) in the United Kingdom.

Gillnets, a common type of fishing gear consisting of vertical walls of nettings invisible to fish, are considered the most deadly gear for seabirds (Dias et al., 2019). Bycatch of seabirds in gillnet 
fisheries alone is estimated to kill ca. 400,000 birds globally each year, with at least 76,000 in the Baltic Sea (Žydelis et al., 2013). Detailed registrations of incidental catches over extended periods are crucial to understand what influences seabird bycatch in time and space, and ultimately how to remedy it (Northridge et al., 2017). Accordingly, recording bycatch of protected species is now a requirement for all EU fisheries (EC, 2016). Yet, reliable data is frequently limited for small-scale and artisanal fisheries (Pott and Wiedenfeld, 2017; ICES, 2018). Worldwide, long-term data series on bycatch remain the exception, and in most regions incidental catches of birds are only sporadically monitored, e.g. through independent on-board observer programmes (Le Bot et al., 2018).

Gillnet fishing fleets often consist of numerous small-scale vessels. In high-waged countries with like Denmark, a regular on-board observer monitoring scheme can rapidly become prohibitively expensive (Kindt-Larsen et al., 2011). Danish commercial gillnetters are mostly vessels below $15 \mathrm{~m}$ in length, and the national on-board observer programme supervised by the National Institute of Aquatic Resources (DTU Aqua) covers only about $0.1 \%$ of the whole fleet (Anonymous 2019). In these conditions, catches of seabirds, rare by nature, are likely to remain undetected. In Denmark, bird bycatches must be reported in fishing logbooks (EC, 2016). However, in small-scale fisheries where no constraining enforcement or verification protocol is in place, self-reported bycatch raises concerns of reliability (Mangi et al., 2015). Indirect observations, e.g. carcass collections and interviews with fishers, can complete the overall picture locally, but also commonly lead to underreporting (see e.g. Bellebaum et al., 2013). Therefore, the characteristics and the magnitude of seabird bycatch in the Danish gillnet fishery are essentially unknown.

Deploying electronic monitoring (EM) systems on fishing vessels offers an alternative to on-board observers, while reducing overall costs (Mangi et al., 2015; Plet-Hansen et al., 2019). EM systems consist of a set of closed-circuit television (CCTV) cameras, gear and position sensors (GPS), and a dedicated computer permanently installed on-board a fishing vessel. The fishing activity is recorded and stored, either locally on a hard drive, or on a dedicated storage server. These data are then readily accessible for researchers to analyse the characteristics of the fishing activity, including distribution of the fishing effort and catch composition. DTU Aqua first started using EM systems in 2008 on commercial trawlers, seiners and gillnetters around Denmark, originally as a means to evaluate discards in these fisheries (Dalskov and Kindt-Larsen, 2009). Rapidly, EM became a tool to assess the effects of the implementation of the European catch quota management system (KindtLarsen et al., 2011; 2012a; Plet-Hansen et al., 2019), and later still, to study incidental catches of marine mammals in the Danish gillnet fisheries (Kindt-Larsen et al., 2012b; 2016). Unlike on-board observers, EM systems are able to follow a fishing vessel all-year long and can potentially record every catch provided that no technical failure occurs and that the system is not tampered with. Using EM, discreet and rare fishing events, such as seabird bycatch, can thus be registered and accounted for.

In the present study, three commercial gillnet vessels operating on the East coast of Denmark were equipped with an electronic monitoring system with CCTV. We recorded the entire fishing activity, including the bycatch of seabirds. Using data spanning from 2010 to 2018, we examined the finescale spatio-temporal variations of the fishing activity, and we estimated the variations of seabird bycatch rates in the study area. Based on these observations, we discuss the ability of EM technologies with CCTV to provide precise information on incidental catches of seabirds in a smallscale gillnet fishery. Such data are valuable both in a fisheries management and in a conservation context, as this issue is often largely ignored in small-scale fisheries. Specifically, we show that EM technologies with CCTV can be used to record incidental catches of seabirds accurately in a commercial gillnet fishery. Then, we describe the seasonal variations of bycatch rates per species in the study area. Finally, we identify the benefits and weaknesses of using EM for collecting seabird bycatch data. 


\section{Material and methods}

\subsection{Study area and sampled fishing vessels}

The data collection was conducted using EM systems on-board three anonymised Danish commercial gillnetters. The periods during which EM was active differed between vessels: vessel 1 was sampled from May 2010 to June 2016, vessel 2 from March 2016 to December 2018, and vessel 3 from May 2010 to April 2014 and from March 2016 to December 2018. The vessels operated in the Sound (Figure 1), an important fishing ground for small-scale gillnetters below $15 \mathrm{~m}$, situated on the Eastern coast of Denmark. Skippers went out for daily coastal trips of a few hours, targeting mostly cod (Gadus morhua) and European plaice (Pleuronectes platessa) year long, with seasonal shift to lumpsucker (Cyclopterus lumpus) between end of January and end of April. Other valuable species included Atlantic salmon (Salmo salar), turbot (Scophthalmus maximus) and Atlantic mackerel (Scomber scombrus).

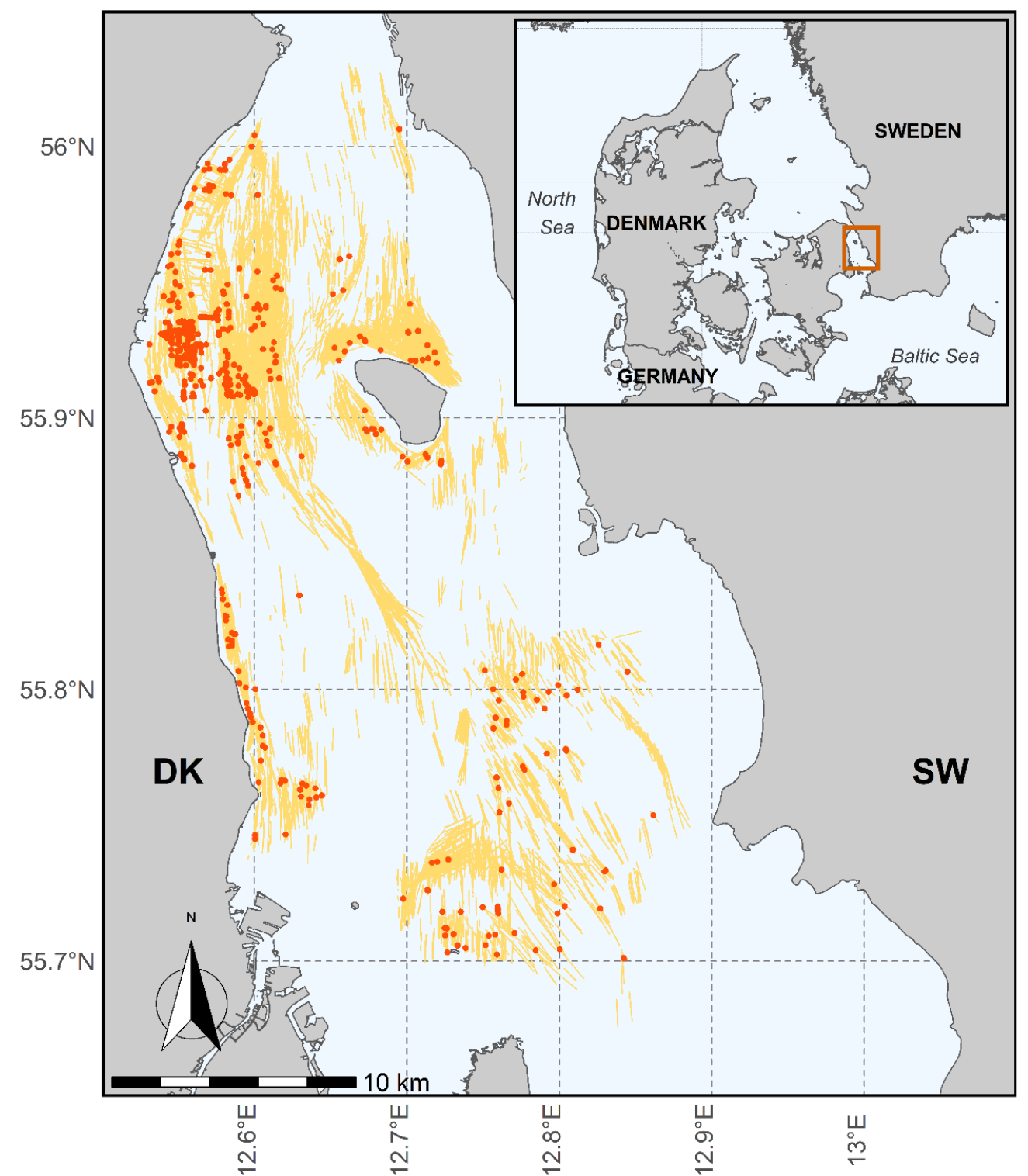
three gillnetters using electronic monitoring for the period 2010-2018. 
The sampled vessels' overall length varied between $9.63 \mathrm{~m}$ and $11.05 \mathrm{~m}$, for a gross tonnage (GT) of 5.8 GT to $10.7 \mathrm{GT}$ and an engine power of $74 \mathrm{~kW}$ to $107 \mathrm{~kW}$. For these small-scale gillnetters, the duration of a fishing trip never exceeded $9 \mathrm{~h}$. All three vessels used traditional monofilament bottom-set gillnets - or rarely trammel nets - with mesh sizes between $120 \mathrm{~mm}$ to $250 \mathrm{~mm}$. Vessels typically set 5 net fleets per fishing trip (median: 5 , mean: 5.2 , sd: 1.9 ), with a net length spanning between $200 \mathrm{~m}$ and $5500 \mathrm{~m}$ (median: $731 \mathrm{~m}$, mean: $790 \mathrm{~m}$, sd: $324 \mathrm{~m}$ ). Most fishing trips consisted of hauling the net fleets set the previous day, but the soak time could be considerably longer when the target species was lumpsucker (median soak time: $13.8 \mathrm{~h}$, mean: $40.8 \mathrm{~h}$, sd: $43.7 \mathrm{~h}$ ). Fishing depth varied considerably between vessels and within vessels along the year. Vessel 1 generally set net fleets in deeper waters (median: $15.0 \mathrm{~m}$, mean: $16.9 \mathrm{~m}$, sd: $10.3 \mathrm{~m}$ ), than the two others (respectively, median: $7 \mathrm{~m}$ and $14 \mathrm{~m}$, mean: $8.0 \mathrm{~m}$ and $13.0 \mathrm{~m}$, sd: $3.4 \mathrm{~m}$ and $3.8 \mathrm{~m}$ ). On occasions, other gears (e.g. pots, fyke nets) were used and the corresponding trips were excluded. One vessel was one-man crewed (vessel 2), while the two others were operating with either one or two crewmembers on deck.

\subsection{EM systems}

Two different EM systems were used to monitor the fishing activity. Originally, two vessels were equipped with EM Observe, a solution developed by Archipelago Marine Research Ltd, Canada (http://www.archipelago.ca). Later, these systems were replaced with Black Box Video, developed by Anchorlab, Denmark (http://www.anchorlab.dk/). The third vessel was also equipped with this system. Both hardware solutions worked on the same general principle: a control box installed in the wheelhouse, associated with 2 to 4 waterproof rugged closed-circuit television (CCTV) cameras recording the activity on deck from different angles, and linked to a position sensor (GPS receiver). A monitor plugged onto the control box allowed checking the camera recordings and the system status. The videos were stored on-board on high-capacity hard drives. For the EM Observe system, once the storage capacity was below $25 \%$, a DTU Aqua staff manually replaced the hard drive with a new one in the control box. The full hard drives were retrieved or sent by mail to DTU Aqua. For the Black Box Video system, data were uploaded to a dedicated server automatically every time the vessel was in an area covered with Wi-Fi or GSM/3G/4G mobile network (e.g. the harbour).

On each vessel, one camera was oriented to observe the net breaking the water surface during the hauling phase, while another camera was placed above the sorting table to monitor catch composition and discard. On one vessel, two additional cameras were installed to record the activity on the deck (Figure 2). All cameras were fixed on existing structures whenever possible, but sometimes the addition of a mounting rack was required to obtain the desired field of view.

The quality of the digital recordings varied considerably between the two EM systems (Table 1). In particular, because it was necessary to replace the full hard drives manually on EM Observe, the number of frames per second ( $f p s)$ and the resolution of the picture were reduced in order to extend the recording time. Conversely, Black Box Video was transmitting data directly over the air, so internal storage capacity was not an issue, and picture quality was thus increased to the maximum. In these conditions, Black Box Video was generally much better at picking up small details in the picture than EM Observe was. 


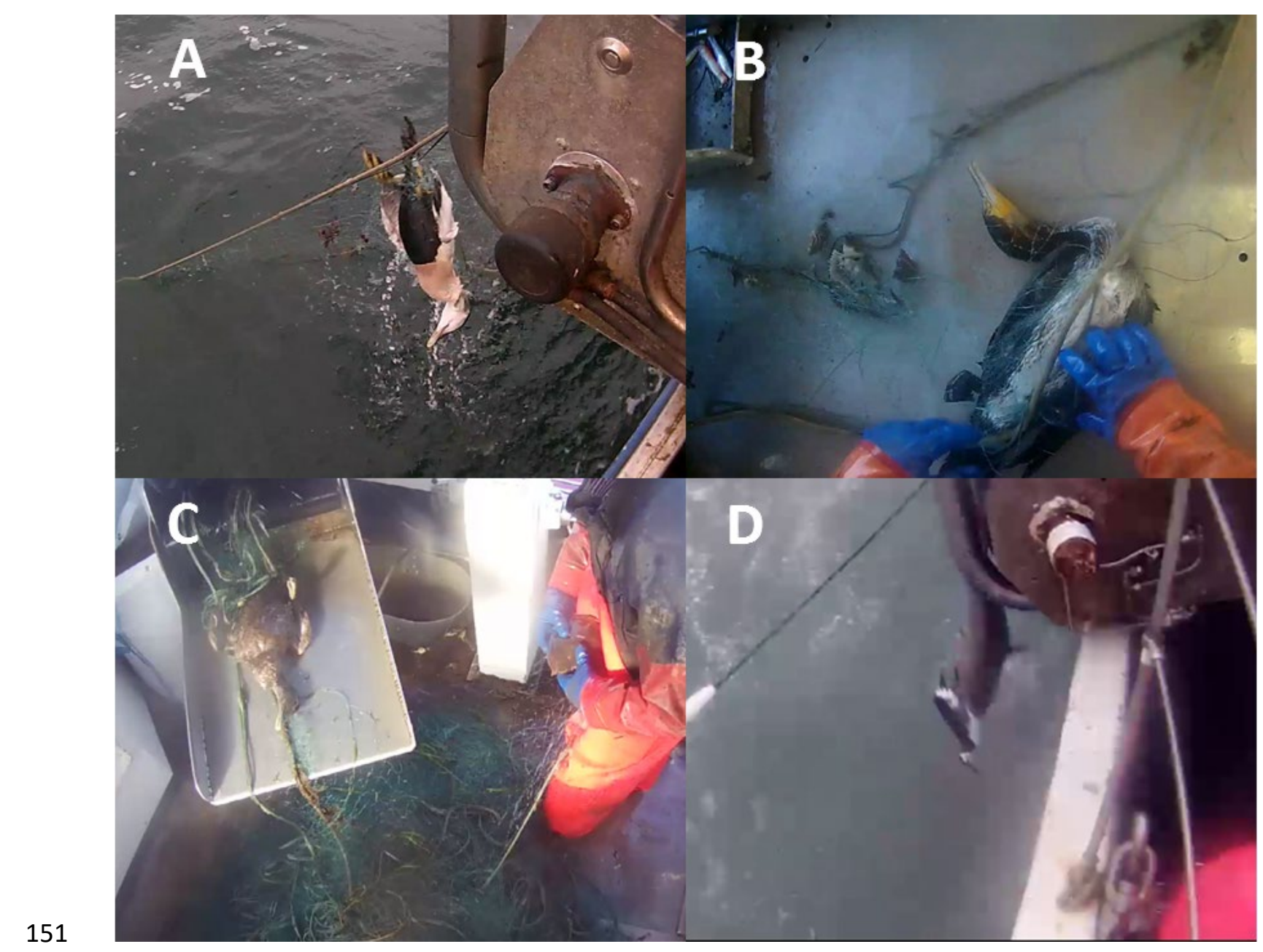

152 Figure 2: Examples of bird bycatch in Black Box Analyzer [A: common eider (Somateria mollissima) adult male; B: great 153 cormorant (Phalacrocorax carbo) immature; C: common eider adult female], and in EMI Observe [D: common guillemot 154 (Uria aalge)].

Table 1: Comparison between the electronic monitoring systems

\begin{tabular}{|c|c|c|c|c|c|}
\hline & \multicolumn{2}{|c|}{ EM Observe } & \multicolumn{3}{|c|}{ Black Box Video } \\
\hline Company & \multicolumn{2}{|c|}{ Archipelago Marine Research Ltd } & \multicolumn{3}{|c|}{ Anchor Lab } \\
\hline Vessel & vessel 1 & vessel 3 & vessel 1 & vessel 2 & vessel 3 \\
\hline Monitoring period & $\begin{array}{l}\text { May } 2010 \text { to } \\
\text { November } 2013\end{array}$ & $\begin{array}{c}\text { March } 2011 \text { to } \\
\text { April } 2014\end{array}$ & $\begin{array}{c}\text { December } 2013 \\
\text { to September } \\
2016 \\
\end{array}$ & $\begin{array}{l}\text { March } 2016 \text { to } \\
\text { December } 2018\end{array}$ & $\begin{array}{l}\text { March } 2016 \text { to } \\
\text { December } 2018\end{array}$ \\
\hline Temporal resolution & \multicolumn{2}{|c|}{$\begin{array}{l}1 \text { GPS position recorded every } 10 \\
\text { seconds }\end{array}$} & \multicolumn{3}{|c|}{1 GPS position recorded every 10 seconds } \\
\hline Lenses & 2.6 to $8 \mathrm{~mm}$ & 2.6 to $8 \mathrm{~mm}$ & 2.6 to $8 \mathrm{~mm}$ & 2.6 to $8 \mathrm{~mm}$ & 2.6 to $8 \mathrm{~mm}$ \\
\hline $\begin{array}{c}\text { Frames per second } \\
\text { (overview) }\end{array}$ & $2 \mathrm{fps}$ & $2 \mathrm{fps}$ & $5 \mathrm{fps}$ & $5 \mathrm{fps}$ & $5 \mathrm{fps}$ \\
\hline $\begin{array}{l}\text { Frames per second } \\
\text { (haul \& catch) }\end{array}$ & 6 to $9 \mathrm{fps}$ & 6 to $9 \mathrm{fps}$ & $5 \mathrm{fps}$ & $5 \mathrm{fps}$ & $5 \mathrm{fps}$ \\
\hline Camera resolution & $640 \times 480$ & $640 \times 480$ & $\begin{array}{c}1280 \times 800 \text { to } \\
1360 \times 768\end{array}$ & $1360 \times 768$ & $1360 \times 768$ \\
\hline $\begin{array}{l}\text { Dedicated software } \\
\text { for data analysis }\end{array}$ & \multicolumn{2}{|c|}{$\begin{array}{c}\text { EM Interpret (Europe release, } \\
\text { Version 11.3.11189) }\end{array}$} & \multicolumn{3}{|c|}{ Black Box Analyzer (Version 4.0.3.0) } \\
\hline
\end{tabular}


157 Analyses of the temporal and spatial characteristics of the fishing trips were done using an electronic monitoring analyser software (EM analyser). Each EM system came with its own dedicated EM analyser (Table 1). Simply put, the recordings made on-board the fishing vessels were stored in a database that associated time, GPS positions and videos. For the end-user, EM analysers presented one or several fishing trips at a time for each vessel, displaying alongside a map with the GPS trace, a timeline indicating the instantaneous vessel speed, and the video recordings from the different cameras.

Analysing video monitoring data is without doubt tedious, and auditing the fishing activity as a fulltime job was considered likely to end up lowering the overall quality of the data. Therefore, for this task, students were hired on $12 \mathrm{~h}$ per week contracts, and taught how to identify the fishing activity and detect seabird bycatch events. Four weeks of initial training with an experienced auditor were necessary before a new recruit could work independently. In addition, a random $10 \%$ check was put into place to verify the quality of the analysed data. In case important differences were found, a senior staff would watch the corresponding footages with the auditor to understand where the errors originated and what to do to remedy them.

Relevant information was inserted manually as notes in the EM analyser software, and consisted of supplementary rows added to the database. These notes included temporal (date and time), spatial (longitude, latitude) and categorical data, and were used to identify the start and end positions of the sets (i.e. the deployment of the net) and of the hauls (i.e. the retrieval of the net), as well as the occurrence of seabird bycatch. The fishing activity (i.e. steaming, hauling or setting nets) was generally detectable using only the speed, position and course of the vessel. Conversely, detecting seabird bycatch events required watching the videos of each individual haul at no more than 3 to 5 times the normal speed, depending on the quality of the recordings. The resulting database was extracted as a spreadsheet for later use in a statistical software.

Some important parameters were not directly available from the EM analyser, e.g. fishing depth and distance to shore. A GIS software was used to obtain these variables respectively by overlaying the vessels' GPS trace with a high-definition bathymetric map provided by DTU Aqua and using an adhoc "distance to feature" function.

\subsection{Video analysis: bird identification}

Each bycatch was identified at the lowest possible level using all characteristic features visible on the videos, i.e. general shape and size, colour(s) of the plumage, beak and feet shape and colour, or any other distinctive clue. When possible, sex and other information related to age (e.g. adult, juvenile, first or second winter, breeding or non-breeding, eclipse plumage for male ducks, etc...) were also recorded. EM analyser software provided the possibility to play the recorded footage frame by frame, zoom onto distinctive anatomical features of the animals (plumage, beak, feet...), use different camera angles and replay the sequences as many times as necessary. Being able to review the key characteristics guaranteed that each individual was identified with the highest degree of certainty (Figure 2). Nevertheless, ambient luminosity, weather, cleanliness of the camera lenses or sun glares could strongly affect the overall readability of the picture and thus the identification process. Likewise, fishers would sometimes block the view of the camera, e.g. when disentangling a bird with their back turned toward the lens. In most cases, at least a few frames were exploitable to identify an animal, but at times, very bad video quality made the identification impossible. Such birds were marked as not identified. 
201 Fishing effort was calculated at a fine scale (in kilometer.hour) as the product of total net fleet length and soak time (i.e. the duration of submersion of gillnet fleets). First, the net fleet length was measured as the distance in a straight line between the positions of the start and of the end of a haul; these were defined as the moments (year, month, day, hour, minute, second) where the beginning of the first panel and the end of last panel of the fleet, respectively, broke the water surface. Next, each set and each haul was assigned a unique time value corresponding to the difference between their respective start and end times. Finally, soak time was approximated as the duration between the averaged time of a set and the averaged time of the matching haul.

Mean yearly bycatch rate estimates and associated confidence intervals were obtained using 100,000 bootstrap iterations. Seabird bycatch per unit effort (BPUE) was calculated using two alternative metrics: number of birds captured per fishing trip $(b p t)$ and number of birds captured per kilometer.hour ( $b k h)$. The former metric is a widely used estimate, useful for comparing BPUE across regions; the latter gave access to a measure of bycatch rates at haul level, using the product of length and soak time of the submerged net fleets.

\subsection{Fishing logbooks}

To verify the completeness of the EM data, official logbooks were collected from the three sampled vessels for the period 2010-2018. Danish fishers are legally bound to fill in these logbooks, which must include information for each individual trip: departure/arrival date and time, type of fishing gear and mesh size, as well as total catch in weight by species by ICES (International Council for the Exploration of the Sea) rectangle. Danish logbooks make no mention of fishing effort in terms of number of nets, soak time or net length. The fishing trips recorded in the EM database were matched to the ones in the logbooks to verify how many trips that actually occurred were missed, i.e. not recorded with the EM systems.

\section{Results}

\subsection{Details of the observed seabird bycatch}

Although a European requirement (EC, 2016), official fishing logbooks did not mention seabird bycatch for any of the sampled gillnetters throughout the time of the study. Instead, the video analysis of the EM data allowed the detection of 700 birds from six different families, most of them identifiable at species level (Table 2 and Figure 3). Only eight animals (1.1\%) could not be identified; yet, although the species could not be determined, the crew's behaviour clearly indicated that these were indeed birds. A fisher disentangling a bird exhibits a different behaviour than if the catch is a fish. That is, the handling of a dead bird usually takes more time than that of a fish, and bird bycatch are normally stored apart from the boxes containing fish, if not directly discarded overboard. The yearlong sampling scheme gave an insight into the species-specific seasonal variations in bird bycatch in the commercial gillnet fishery taking place in the Sound. Table 2 presents the bycatch records per season and the associated bycatch per unit effort (BPUE) estimates. Anecdotally, a dozen seagulls and great cormorants (Phalacrocorax carbo) were entangled while trying to predate on discards; all the affected animals were swiftly freed and released alive by the fishers and did not seem to suffer any injuries. These events were not recorded as bycatch. 
Table 2: Seasonal variations of the number of birds taken as bycatch in gillnets, grouped by family and species; the corresponding bycatch per unit effort (expressed as the number of birds per kilometer.hour) is indicated in the parentheses. The identification is given at the lowest possible level (species, genus, family). Data were recorded on three electronically monitored Danish commercial gillnetters in the Sound for the period 2010-2018 (spring = MarchMay; summer = June-August; fall = September-November; winter $=$ December-February).

\begin{tabular}{|c|c|c|c|c|c|c|c|}
\hline Family & Species & $\begin{array}{l}\text { \% total } \\
\text { bycatch }\end{array}$ & Spring & Summer & Fall & Winter & YEAR \\
\hline \multirow[t]{3}{*}{ Anatidae } & $\begin{array}{l}\text { Common eider } \\
\text { Somateria mollissima }\end{array}$ & 58.4 & $\begin{array}{c}n=106 \\
(0.000606)\end{array}$ & $\begin{array}{c}n=14 \\
(0.000289)\end{array}$ & $\begin{array}{c}n=236 \\
(0.054200)\end{array}$ & $\begin{array}{c}n=53 \\
(0.007150)\end{array}$ & $\begin{array}{c}n=409 \\
(0.001758)\end{array}$ \\
\hline & $\begin{array}{l}\text { Scoter } \\
\text { Melanitta spp. }\end{array}$ & 3.1 & $\begin{array}{c}n=2 \\
(0.000007)\end{array}$ & - & $\begin{array}{c}n=18 \\
(0.000383)\end{array}$ & $\begin{array}{c}n=2 \\
(0.000006)\end{array}$ & $\begin{array}{c}n=22 \\
(0.000099)\end{array}$ \\
\hline & Not identified & 0.4 & $\begin{array}{c}n=2 \\
(0.000008)\end{array}$ & - & $\begin{array}{c}n=1 \\
(0.000026)\end{array}$ & - & $\begin{array}{c}n=3 \\
(0.000009)\end{array}$ \\
\hline Phalacrocoracidae & $\begin{array}{l}\text { Great cormorant } \\
\text { Phalacrocorax carbo }\end{array}$ & 19.6 & $\begin{array}{c}n=2 \\
(0.000008)\end{array}$ & $\begin{array}{c}n=15 \\
(0.000417)\end{array}$ & $\begin{array}{c}n=84 \\
(0.002272)\end{array}$ & $\begin{array}{c}n=36 \\
(0.009180)\end{array}$ & $\begin{array}{c}n=137 \\
(0.009040)\end{array}$ \\
\hline \multirow[t]{3}{*}{ Alcidae } & $\begin{array}{l}\text { Common guillemot } \\
\text { Uria aalge }\end{array}$ & 12.4 & $\begin{array}{c}n=1 \\
(0.000003)\end{array}$ & - & $\begin{array}{c}n=39 \\
(0.001335)\end{array}$ & $\begin{array}{c}n=47 \\
(0.001954)\end{array}$ & $\begin{array}{c}n=87 \\
(0.000823)\end{array}$ \\
\hline & $\begin{array}{l}\text { Razorbill } \\
\text { Alca torda }\end{array}$ & 2.3 & - & $\begin{array}{c}n=1 \\
(0.000024)\end{array}$ & $\begin{array}{c}n=8 \\
(0.000136)\end{array}$ & $\begin{array}{c}n=7 \\
(0.000096)\end{array}$ & $\begin{array}{c}n=16 \\
(0.000064)\end{array}$ \\
\hline & Not identified & 1.0 & $\begin{array}{c}n=4 \\
(0.000013)\end{array}$ & - & $\begin{array}{c}n=3 \\
(0.000077)\end{array}$ & - & $\begin{array}{c}n=7 \\
(0.000023)\end{array}$ \\
\hline Laridae & $\begin{array}{l}\text { Gull } \\
\text { Larus spp. }\end{array}$ & 0.4 & $\begin{array}{c}n=1 \\
(0.000002)\end{array}$ & $\begin{array}{c}n=1 \\
(0.000014)\end{array}$ & $\begin{array}{c}n=1 \\
(0.000011)\end{array}$ & - & $\begin{array}{c}n=3 \\
(0.000007)\end{array}$ \\
\hline Gavidae & $\begin{array}{l}\text { Loon } \\
\text { Gavia spp. }\end{array}$ & 0.6 & $\begin{array}{c}n=1 \\
(0.000005)\end{array}$ & - & $\begin{array}{c}n=3 \\
(0.000073)\end{array}$ & - & $\begin{array}{c}n=4 \\
(0.000019)\end{array}$ \\
\hline \multirow[t]{2}{*}{ Podicipedidae } & $\begin{array}{l}\text { Great crested grebe } \\
\text { Podiceps cristatus }\end{array}$ & 0.4 & - & - & - & $\begin{array}{c}n=3 \\
(0.000047)\end{array}$ & $\begin{array}{c}n=3 \\
(0.000012)\end{array}$ \\
\hline & $\begin{array}{l}\text { Red-necked grebe } \\
\text { Podiceps grisegena }\end{array}$ & 0.1 & - & $\begin{array}{c}n=1 \\
(0.000031)\end{array}$ & - & - & $\begin{array}{c}n=1 \\
(0.000008)\end{array}$ \\
\hline \multicolumn{2}{|l|}{ Unidentified bird } & 1.1 & $\begin{array}{c}n=1 \\
(0.000002)\end{array}$ & $\begin{array}{c}n=1 \\
(0.000007)\end{array}$ & $\begin{array}{c}n=2 \\
(0.000033)\end{array}$ & $\begin{array}{c}n=4 \\
(0.000093)\end{array}$ & $\begin{array}{c}n=8 \\
(0.000034)\end{array}$ \\
\hline All birds & & $100 \%$ & $\begin{array}{c}n=120 \\
(0.000653)\end{array}$ & $\begin{array}{c}n=33 \\
(0.000782)\end{array}$ & $\begin{array}{c}n=395 \\
(0.009430)\end{array}$ & $\begin{array}{c}n=152 \\
(0.003142)\end{array}$ & $\begin{array}{c}n=700 \\
(0.003300)\end{array}$ \\
\hline
\end{tabular}

Generally, bird bycatch, when reported (e.g. using official logbooks), is not associated to a specific position, but is instead mentioned as number of birds per fishing trip per statistical area (e.g. ICES statistical rectangle level). Therefore, having access to the exact coordinates of every incidental catch was a major benefit of using electronic monitoring (Figure 3). 


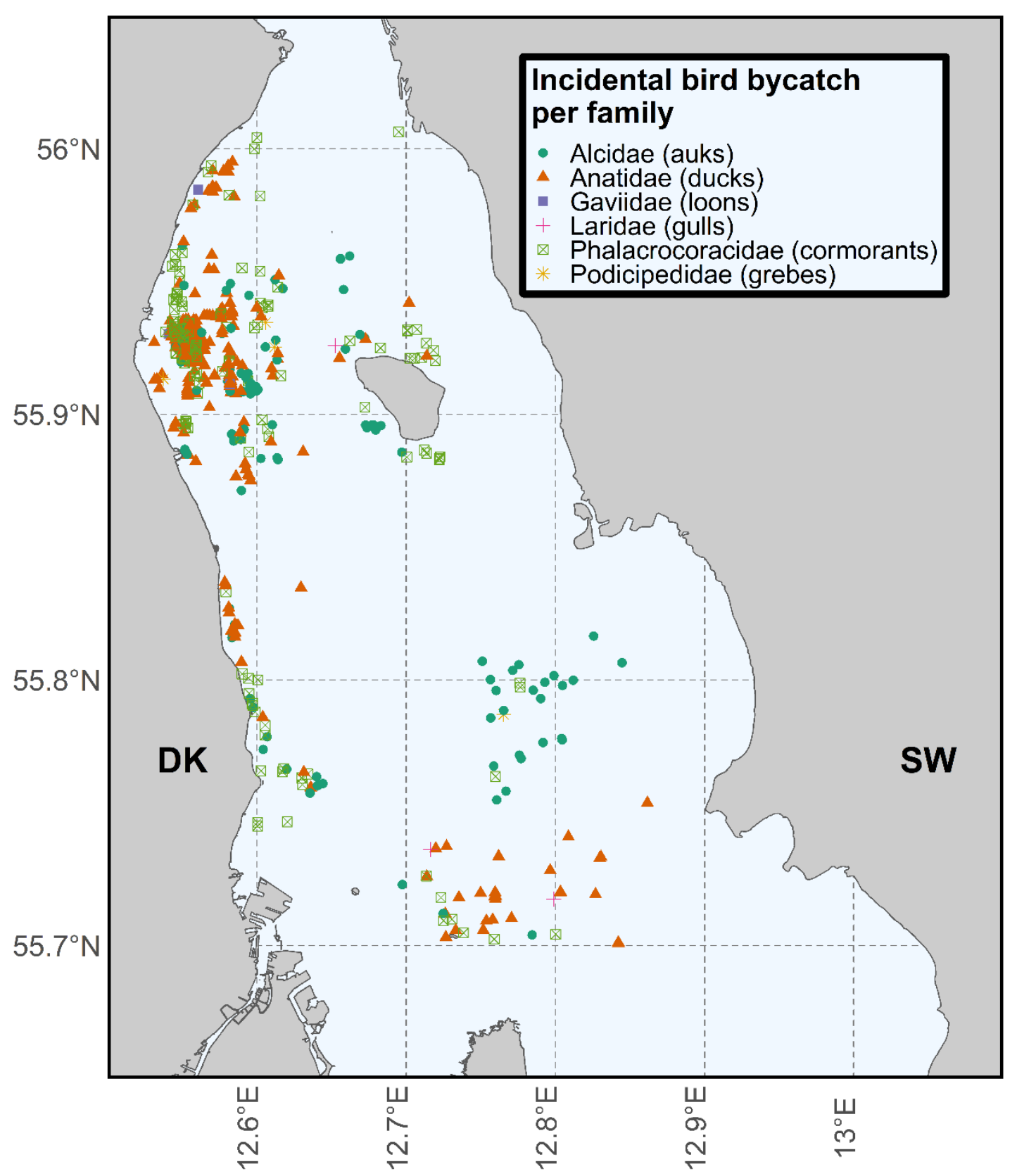

Figure 3: Positions of the incidental catch of seabirds in gillnet recorded using EM and grouped by families.

Moreover, electronic monitoring provided information on the structure of the populations of seabirds captured in gillnets. Some groups of seabirds, e.g. ducks (Anatidae), display characteristic dimorphism between sexes, or between juveniles, immatures and adults. In particular, it was possible to identify the sex and maturity (adult or juvenile) of the common eiders (Somateria mollissima) taken as bycatch, and to distinguish juvenile (or immature) great cormorants from breeding and non-breeding adults (Table 3). Male common eiders represented $69.7 \%$ of the catches and females $23.0 \%$, the rest being juveniles (3.4\%) and unidentifiable individuals (3.9\%). Bycatch of great cormorant was dominated by juvenile and immature birds (56.2\%), while adult birds made up less than a third of the yearly average bycatch. However, due to a system failure, 21 individuals (i.e. about $15 \%$ ) could not be classified. The reason for this is that some of the oldest video data, where these bycatches were recorded, were lost; species identification had been done prior to the data loss, but not the aging of the birds. 
Table 3: Bycatch composition for the two bird species the most frequently captured in gillnets in the Sound, the common eider and the great cormorant, per season (spring = March-May; summer = June-August; fall = September-November; winter $=$ December-February) for the period 2010-2018. The number of observations per group is indicated in the parentheses.

\begin{tabular}{|l|l|l|l|l|l|l|}
\hline Species & Status & Spring & Summer & Fall & Winter & $\begin{array}{l}\text { Yearly } \\
\text { average }\end{array}$ \\
\hline \multirow{5}{*}{ Common eider } & Female & $\begin{array}{l}16.0 \% \\
(n=17)\end{array}$ & $\begin{array}{l}28.6 \% \\
(n=4)\end{array}$ & $\begin{array}{l}25.0 \% \\
(n=59)\end{array}$ & $\begin{array}{l}26.4 \% \\
(n=14)\end{array}$ & $\mathbf{2 3 . 0 \%}$ \\
\cline { 2 - 7 } & Male & $\begin{array}{l}75.5 \% \\
(n=80)\end{array}$ & $\begin{array}{l}42.9 \% \\
(n=6)\end{array}$ & $\begin{array}{l}69.5 \% \\
(n=164)\end{array}$ & $\begin{array}{l}66.0 \% \\
(n=35)\end{array}$ & $\mathbf{6 9 . 7 \%}$ \\
\cline { 2 - 7 } & $\begin{array}{l}\text { Juvenile } \\
\text { (undetermined sex) }\end{array}$ & $\begin{array}{l}4.7 \% \\
(n=5)\end{array}$ & $\begin{array}{l}0.0 \% \\
(n=0)\end{array}$ & $\begin{array}{l}2.5 \% \\
(n=6)\end{array}$ & $\begin{array}{l}5.7 \% \\
(n=3)\end{array}$ & $\mathbf{3 . 4 \%}$ \\
\cline { 2 - 7 } & Unidentified & $\begin{array}{l}3.8 \% \\
(n=4)\end{array}$ & $\begin{array}{l}28.6 \% \\
(n=4)\end{array}$ & $\begin{array}{l}3.0 \% \\
(n=7)\end{array}$ & $\begin{array}{l}1.9 \% \\
(n=1)\end{array}$ & $\mathbf{3 . 9 \%}$ \\
\hline & $\begin{array}{l}\text { Adult (breeding and } \\
\text { non-breeding) }\end{array}$ & $\begin{array}{l}50.0 \% \\
(n=1)\end{array}$ & $\begin{array}{l}6.7 \% \\
(n=1)\end{array}$ & $\begin{array}{l}33.3 \% \\
(n=28)\end{array}$ & $\begin{array}{l}25.0 \% \\
(n=9)\end{array}$ & $\mathbf{2 8 . 5 \%}$ \\
\cline { 2 - 7 } & $\begin{array}{l}\text { Juvenile and } \\
\text { immature }\end{array}$ & $\begin{array}{l}0.0 \% \\
(n=0)\end{array}$ & $\begin{array}{l}66.7 \% \\
(n=10)\end{array}$ & $\begin{array}{l}50.0 \% \\
(n=42)\end{array}$ & $\begin{array}{l}69.4 \% \\
(n=25)\end{array}$ & $\mathbf{5 6 . 2 \%}$ \\
\cline { 2 - 7 } & Unidentified & $\begin{array}{l}50.0 \% \\
(n=1)\end{array}$ & $\begin{array}{l}26.7 \% \\
(n=4)\end{array}$ & $\begin{array}{l}16.7 \% \\
(n=14)\end{array}$ & $\begin{array}{l}5.6 \% \\
(n=2)\end{array}$ & $\mathbf{1 5 . 3 \%}$ \\
\hline
\end{tabular}

Through the study periods, official logbooks recorded 2748 fishing trips in total, while sensor data from EM systems recorded 2118 trips, consisting of 10964 hauls (Table 4). Fishing trips registered in official logbooks and recorded using electronic monitoring could in general be linked together, although some gaps were found (Table 4 and Table 5). Unrecorded trips in the EM system resulted from occasional technical issues, e.g. GPS sensor defects or power failure in the wheelhouse. These failures often required to send a technician on-board the fishing vessel to fix the problem, and could sometimes last for extended periods (e.g. vessel 2). A number of trips (78) that were recorded with electronic monitoring were not mentioned in the official logbooks. On one vessel, a closer look at the logbook data showed that, sometimes, the skipper aggregated two consecutive trips into one or that some fishing trips were simply not registered at all. Therefore, and although the logbooks are normally assumed to provide an exact measure of the fishing effort, a small uncertainty exists concerning the real number of fishing trips per vessel over the whole study period. Furthermore, the mean monthly fishing effort varied considerably along the year between and within vessels (Table 5). For example, in case of adverse weather conditions or strong currents that could damage their nets, skippers normally choose to stay in harbour. 
Table 4: Comparison between the numbers of trips registered in logbooks and recorded with the EM systems. The years indicate the periods where electronic monitoring was active for each vessel. The total number of hauls recorded and analysed using electronic monitoring are indicated per vessel, as well as the corresponding number of hauls per trip ( \pm 1 standard deviation).

\begin{tabular}{|l|l|l|l|}
\hline VESSEL & $\begin{array}{l}\text { Total number of } \\
\text { fishing trips (from } \\
\text { logbooks) }\end{array}$ & $\begin{array}{l}\text { Number of fishing } \\
\text { trips recorded with } \\
\text { EM (\% covered) }\end{array}$ & $\begin{array}{l}\text { Number of hauls } \\
\text { recorded with EM } \\
\text { (mean number of } \\
\text { hauls per trip } \pm \text { sd) }\end{array}$ \\
\hline $\begin{array}{l}\text { Vessel } 1 \\
(2010-2016)\end{array}$ & 1344 & $1197(89 \%)$ & $\begin{array}{l}6798 \\
(3.70 \pm 2.17)\end{array}$ \\
\hline $\begin{array}{l}\text { Vessel } 2 \\
(2016-2018)\end{array}$ & 436 & $196(45 \%)$ & $\begin{array}{l}532 \\
(2.10 \pm 1.14)\end{array}$ \\
\hline $\begin{array}{l}\text { Vessel 3 } \\
(2010-2014 \text { and 2016- } \\
2018)\end{array}$ & 968 & $725(75 \%)$ & $\begin{array}{l}3635 \\
(3.16 \pm 1.66)\end{array}$ \\
\hline TOTAL & 2748 & $2118(77 \%)$ & $\begin{array}{l}10965 \\
(3.44 \pm 2.02)\end{array}$ \\
\hline
\end{tabular}

Table 5: Comparison of the mean number of fishing trips per month per vessel recorded using EM (in bold) and registered in logbooks (in italics in parentheses). The years indicate the periods where electronic monitoring was active for each vessel.

\begin{tabular}{|c|c|c|c|c|c|c|c|c|c|c|c|c|}
\hline Vessel & Jan & Feb & Mar & Apr & May & June & July & Aug & Sep & Oct & Nov & Dec \\
\hline $\begin{array}{l}\text { Vessel } 1 \\
(2010-2016)\end{array}$ & $\begin{array}{l}22.3 \\
(23.2)\end{array}$ & $\begin{array}{l}\mathbf{1 5 . 5} \\
(16.2)\end{array}$ & $\begin{array}{l}21.5 \\
(21.2)\end{array}$ & $\begin{array}{l}9.0 \\
(7.8)\end{array}$ & $\begin{array}{l}17.0 \\
(21.0)\end{array}$ & $\begin{array}{l}20.5 \\
(20.0)\end{array}$ & $\begin{array}{l}14.6 \\
(15.7)\end{array}$ & $\begin{array}{l}13.3 \\
(18.0)\end{array}$ & $\begin{array}{l}15.0 \\
(20.2)\end{array}$ & $\begin{array}{l}19.8 \\
(23.5)\end{array}$ & $\begin{array}{l}\mathbf{2 3 . 0} \\
(23.5)\end{array}$ & $\begin{array}{l}19.7 \\
(18.7)\end{array}$ \\
\hline $\begin{array}{l}\text { Vessel } 2 \\
(2016-2018)\end{array}$ & $\begin{array}{l}5.0 \\
(10.0)\end{array}$ & $\begin{array}{l}8.0 \\
(9.5)\end{array}$ & $\begin{array}{l}7.3 \\
(14.0)\end{array}$ & $\begin{array}{l}5.3 \\
(14.0)\end{array}$ & $\begin{array}{l}3.5 \\
(13.7)\end{array}$ & $\begin{array}{l}7.5 \\
(11.0)\end{array}$ & $\begin{array}{l}6.0 \\
(11.0)\end{array}$ & $\begin{array}{l}4.0 \\
(16.3)\end{array}$ & $\begin{array}{l}\mathbf{1 0 . 3} \\
\text { (14.3) }\end{array}$ & $\begin{array}{l}7.3 \\
(10.7)\end{array}$ & $\begin{array}{l}\mathbf{1 0 . 0} \\
(18.0)\end{array}$ & $\begin{array}{l}5.0 \\
(9.3)\end{array}$ \\
\hline $\begin{array}{l}\text { Vessel } 3 \\
\text { (2010-2014; } \\
\text { 2016-2018) }\end{array}$ & $\begin{array}{l}6.0 \\
(7.8)\end{array}$ & $\begin{array}{l}\mathbf{1 4 . 3} \\
\text { (13.2) }\end{array}$ & $\begin{array}{l}17.8 \\
\text { (19.8) }\end{array}$ & $\begin{array}{l}7.8 \\
(10.3)\end{array}$ & $\begin{array}{l}20.2 \\
(23.2)\end{array}$ & $\begin{array}{l}19.2 \\
\text { (23.3) }\end{array}$ & $\begin{array}{l}20.8 \\
(23.0)\end{array}$ & $\begin{array}{l}19.2 \\
(19.2)\end{array}$ & $\begin{array}{l}10 \\
(12.7)\end{array}$ & $\begin{array}{l}\mathbf{0} \\
(4.0)\end{array}$ & $\begin{array}{l}4.0 \\
(19.8)\end{array}$ & $\begin{array}{l}9.7 \\
(16.3)\end{array}$ \\
\hline
\end{tabular}

\subsection{Bycatch rate estimates}

Bycatch of birds occurred in $13.3 \%$ of the fishing trips recorded with $E M$ and in $3.5 \%$ of the hauls. A few mass bycatch events may have had an overly strong influence on the mean bycatch rate estimates (Table 2). Especially, estimated bycatch per unit effort (BPUE) rates observed in November were higher than for any other months, notably because of several extreme bycatch events recorded in 2014. In fact, in $95 \%$ of the trips where bycatch was observed, no more than six birds per trip were captured, while in the remaining $5 \%$, up to 57 birds per trip were taken as bycatch. These $5 \%$ 
represented only 14 out of 2118 fishing trips, but accounted for $40 \%$ of the total incidental catch of seabirds observed during the study.

In order to visualise the influence of rare mass bycatch events on mean bycatch rate estimates, BPUE was calculated both with the full dataset (Figure 4), and after having excluded the 14 fishing trips where more than six birds had been captured (Figure 5).
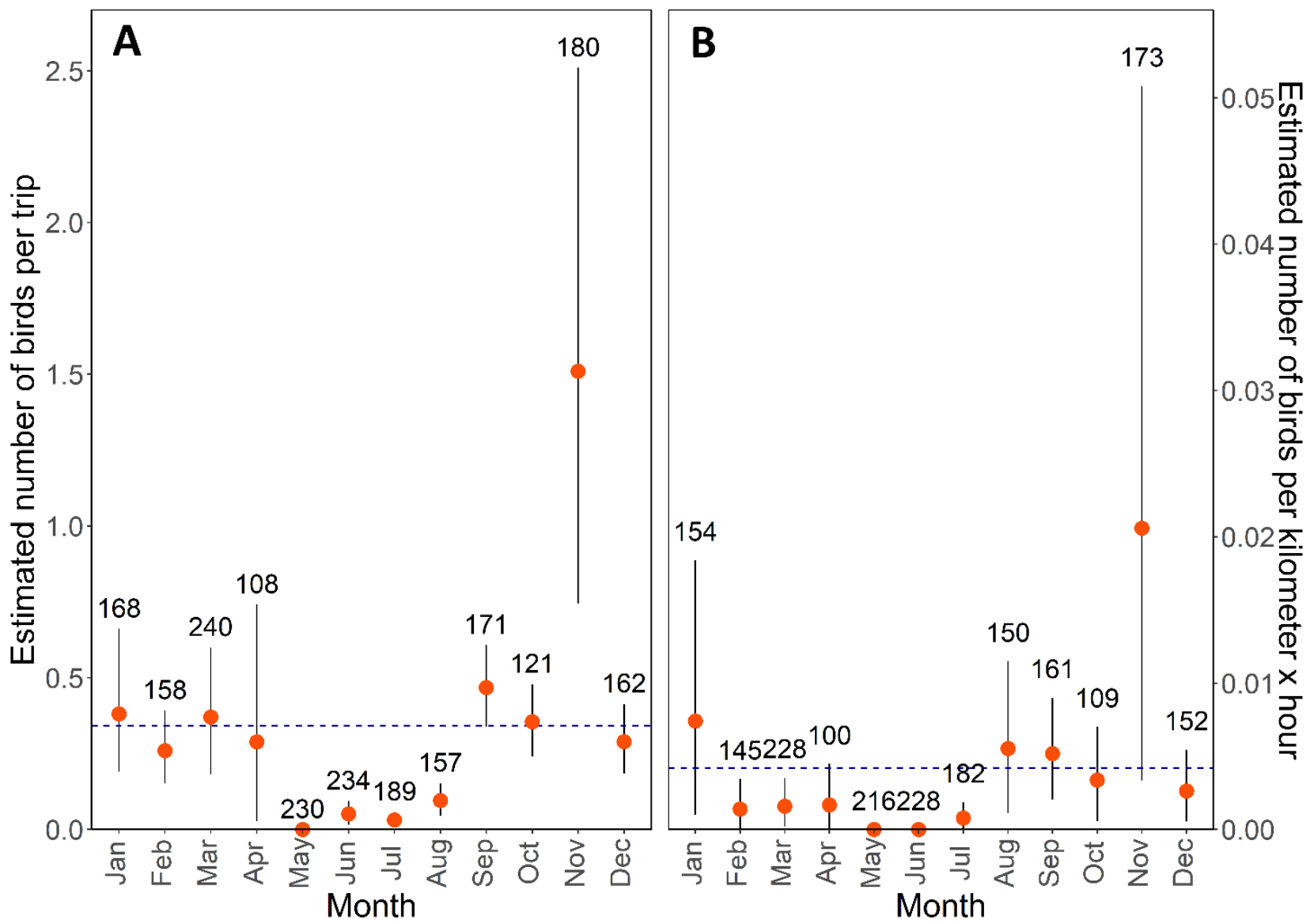

Figure 4: Monthly estimated bycatch per unit effort (BPUE). A. Total number of incidental bird bycatch per fishing trip; B. Total number of incidental bird bycatch per kilometer.hour. Orange dot: mean BPUE estimates; plain black bars: $95 \%$ confidence intervals; dashed blue bar: average yearly bycatch rate. The total number of fishing trips for each month is indicated on top of the $\mathrm{Cl}$ bars. The estimates are based on 100,000 bootstrap repetitions.

Using the full dataset, mean BPUE was estimated at 0.00418 bird per kilometer.hour (95\% confidence interval: 0.00075 to $0.00966 ; 100000$ bootstraps), or 0.34 bird per trip ( $95 \%$ confidence interval: 0.18 to $0.56 ; 100000$ bootstraps), with important variation between months (Figure 4). The reduced dataset containing only the fishing trips where no more than 6 birds had been captured led to an estimated yearly average of 0.0026 bird per kilometer.hour ( $95 \%$ confidence interval: 0.0006 to $0.0052 ; 100000$ bootstraps), and 0.21 bird per trip (95\% confidence interval: 0.14 to $0.30 ; 100$ 000 bootstraps) (Figure 5). 

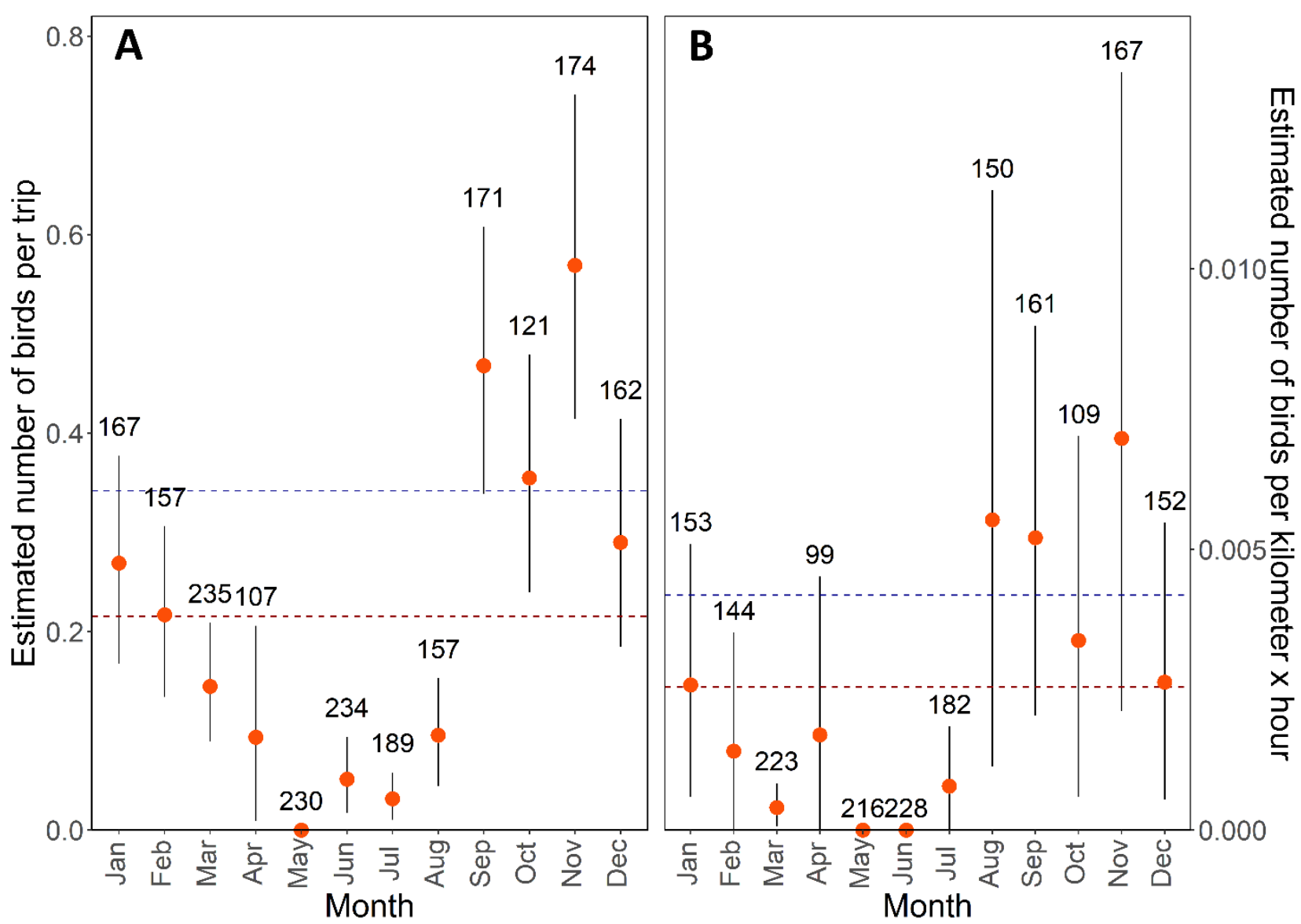

Figure 5: Monthly estimated bycatch per unit effort (BPUE), after excluding the 14 most extreme bycatch events, corresponding to the $5 \%$ upper quantile: A. Total number of incidental bird bycatch per fishing trip; $B$. Total number of incidental bird bycatch per kilometer.hour. Orange dot: mean BPUE estimates; plain black bars: $95 \%$ confidence intervals; dashed red bar: average yearly bycatch rate excluding the 14 fishing trips where more than six birds were captured (i.e. $95 \%$ of the trips with bycatch); dashed blue bar: average yearly bycatch rate including the whole dataset. The total number of fishing trips for each month is indicated on top of the $\mathrm{Cl}$ bars. The estimates are based on 100,000 bootstrap repetitions.

In the full dataset, the influence of mass bycatch events on BPUE estimates was clear. November in particular stood out as the month where birds were the most at risk of drowning in fishing nets. Overall, fall and winter were the seasons for which the rate of incidental catch was the highest, when many seabirds use the Sound as a feeding and resting ground. The period between the end of spring and summer showed in comparison very few occurrences of bycatch. Seasonal variations of 
BPUE also revealed a spatial component (Figure 6), with important local differences in mean bycatch rates between seasons, indicating potential seasonal bycatch hotspots.
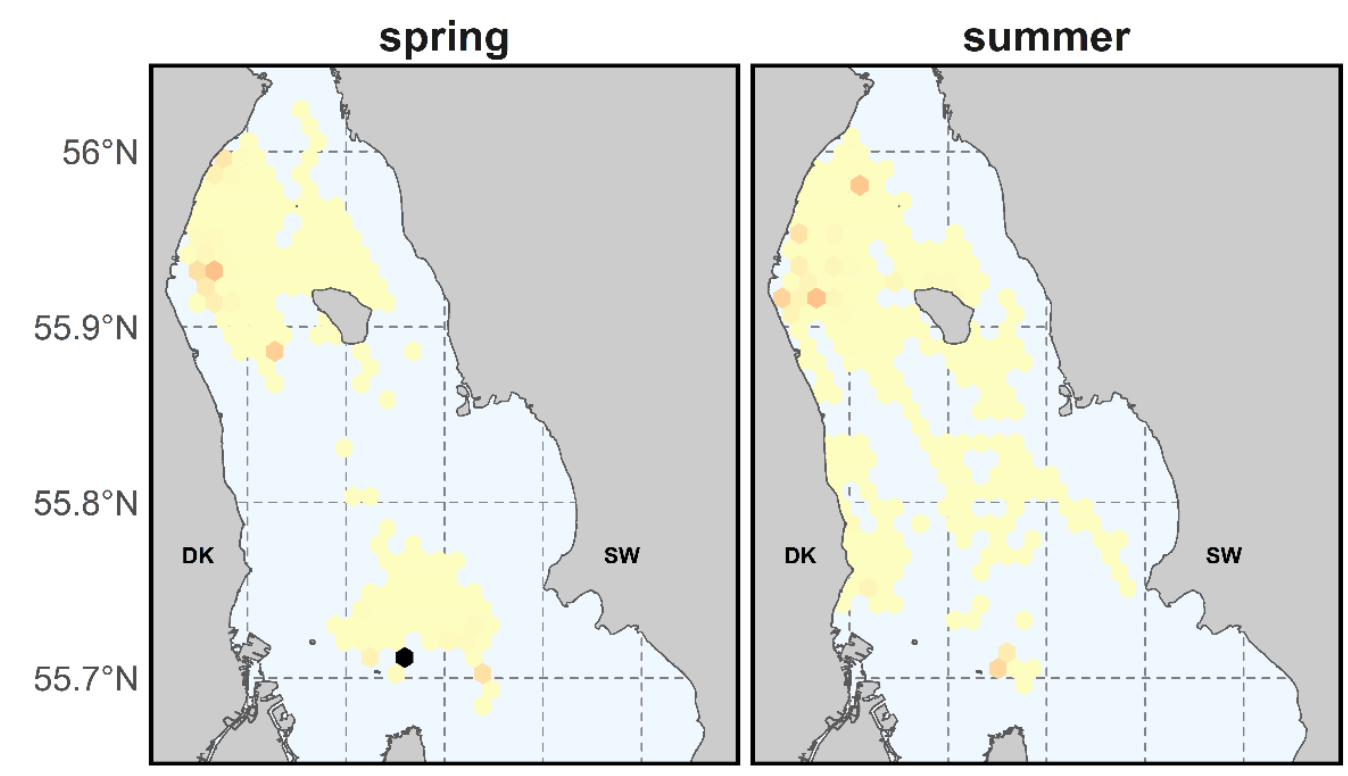

BPUE (birds per km.hour)
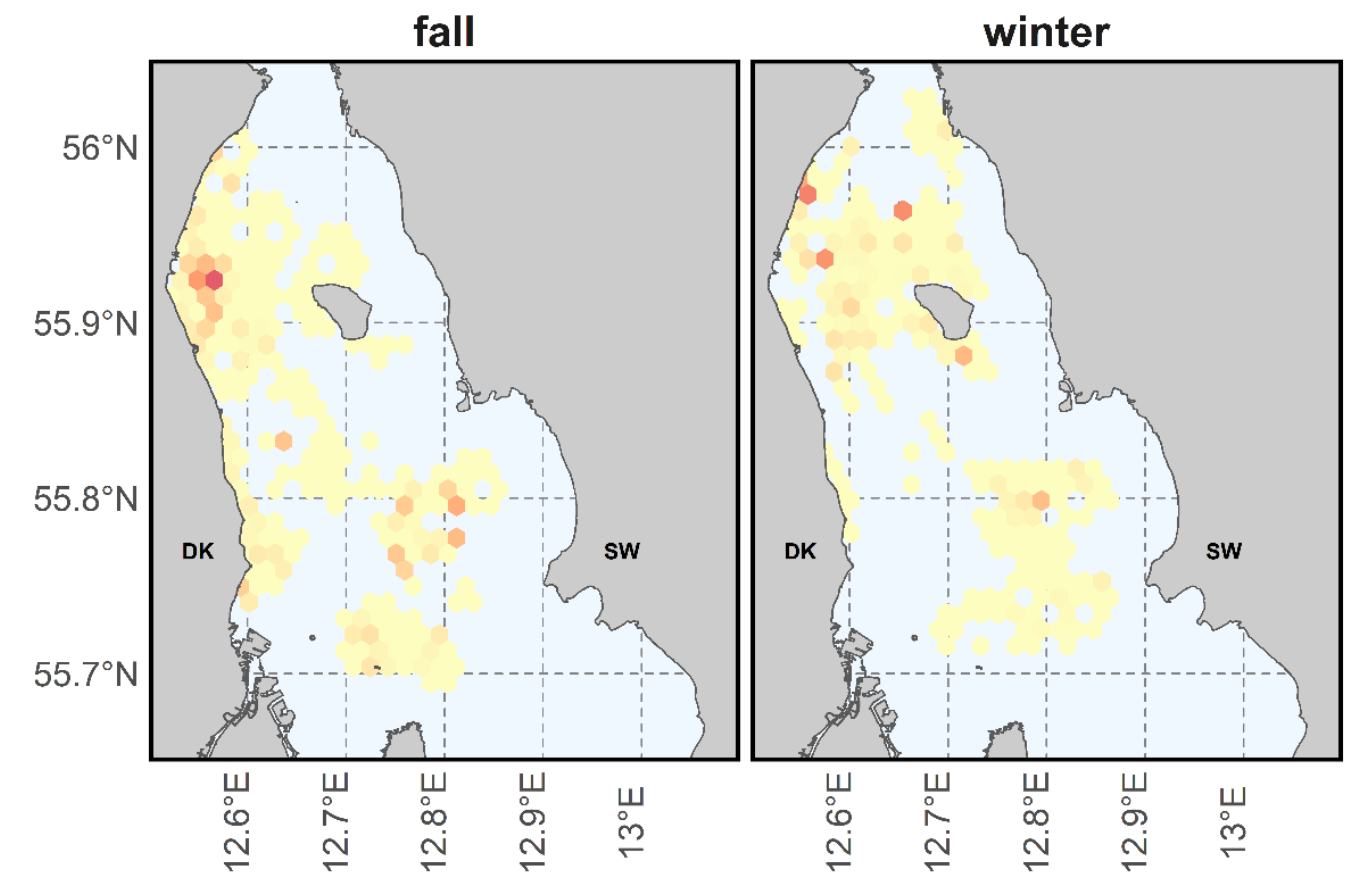

0.20

0.15

0.10 0.05 0.00

Figure 6: Seasonal variations in mean estimated bycatch per unit effort (in number of bird per kilometer.hour) in the Sound for the period 2010-2018 (spring = March-May; summer = June-August; fall = September-November; winter = December-February).

\section{Discussion}

There is a relative lack of knowledge on the overall impact of fishing on seabird populations in Europe (EC, 2012). In this context, the present paper demonstrates the feasibility of using electronic monitoring (EM) systems to collect long fine-scale time-series of incidental catch of seabirds in commercial fisheries. In this study, whereas no bycatch was reported in official logbooks, EM systems were able to detect incidental catches of seabirds. Bycatch could be identified at species level, with only $1.1 \%$ of the 700 specimen remaining unidentified (Table 2 ). Combined with the exact 
position of the fishing gears and the precise duration of soak time, EM allowed measuring fishing effort at high-resolution (spatial and temporal). The systems offered the possibility to calculate estimates of bird bycatch per unit effort (BPUE) at haul level (Figure 4), thus uncovering potential areas of high risk of bycatch (Figure 6). In addition, for some bird species with plumage dissimilarities between sex (e.g. common eider), or between juveniles and adults (e.g. great cormorant), it was possible to establish ratios revealing differences in bycatch risks between groups of individuals of the same species (Table 3).

The quality of bycatch data collected using CCTV monitoring is highly dependent on the quality of the videos on the one hand, and on the other hand, on the ability of the video analysts to detect bycatch. The EM systems, in particular the cameras, were upgraded in 2014. At first, the main motivation for this change was to provide a more convenient workflow for the analysts, and to reduce the risk of data loss by going from manual data acquisition (postal delivery of the hard drives) to automatized over-the-air data acquisition. In the first part of the study, to reduce the number of postal shipments to a minimum, the Archipelago EM Observe systems were set up to maximize the recording time by limiting the video quality in terms of $\mathrm{fps}$ and resolution. After the change to the Black Box Video system, internal storage capacity was not an issue anymore, so the video quality was increased accordingly: higher resolution, higher number of frames per seconds, better contrasts (Table 1). Nevertheless, even with the best cameras installed on-board, the readability of the recorded footage still degrades quickly if the lenses are covered with smudge, water droplets or salt crusts. It was therefore essential to contact skippers regularly to re-address the importance of frequently wiping clean the cameras and to use simple prevention measures such as applying rain repellent on the lenses.

Another recurring concern is to maintain the capacity of the human analysts to correctly and consistently identify the fishing activity (anchor sets, retrieving of the nets, bycatch). Sometimes, unanticipated events may occur, and a critical eye is necessary to understand and judge the situation correctly. This is particularly true for gillnet fisheries when estimating soak time from EM recordings. For instance, after a storm, a net fleet might have been broken apart and scattered. Associating the correct set, and thus the correct soak duration, to each net fragment requires high focus. Generally, hours on end of video analysing leads to mental fatigue for the analysts. Therefore, video auditors were asked to work no more than $6 \mathrm{~h}$ daily with a pause every $2 \mathrm{~h}$ in order to maintain the required level of concentration. Another incentive to keep standards high is to operate random quality checks on already audited data. Moreover, feedback from the EM analysts is essential. Regular meetings with the whole team to discuss possible methodological improvement, data flaws and to plan future work clearly improved the quality of the bycatch data collection over time.

Besides human operators, computer-assisted image recognition, artificial intelligence and deeplearning algorithms were initially considered to facilitate and speed up the analysing process. These fields of research are progressing rapidly (e.g. Chen et al., 2014; Niemi and Tanttu, 2018; Hong et al., 2019). Still, at the time the study started, no algorithm could perform better than a trained human being does, at least not with data from small-scale vessels. Standardising video footage might help accelerate the development of efficient image-recognition software. However, EM systems are always customised configurations, which are adapted to specific vessel's characteristics, e.g. in terms of camera placement, arrangement of deck and fishing procedures. Obtaining standardised images for all small-scale vessels is therefore unrealistic. Nonetheless, there is no doubt that in a near future, these technologies will be mature enough to be implemented in operational electronic monitoring systems.

Even if the analysts assess the videos from the fishing vessels with the greatest care, there is always a risk of missing an inconspicuous bird. Ideally, vessels participating in such a study should at least register the number of bycatch per fishing trip - and if possible the species - as is already a 
requirement in the European Union (EC, 2016). Nevertheless, the accuracy of fisher-reported data is questionable (Mangi et al., 2015). Skippers may make mistakes filling in logbooks (Kindt-Larsen et al., 2011). Regarding bycatch of protected species, some authors report a systematic lack of congruence between EM data (and/or on-board observers data) and logbook data (Macbeth et al., 2018; Emery et al., 2019). Fishers may also sometimes simply miss a bycatch, e.g. if a bird falls from the net before being hauled up on board. Therefore, EM analysts should treat logbook data with a grain of salt, and they should not only audit the days where fishers registered bycatch.

Bearing in mind that the quality of the data collected with EM was not always optimal and that some fishing trips were not recorded in the first place (Table 4), the bird bycatch per unit effort (BPUE) estimations presented in this study should be considered as conservative. Yet, the overall temporal trend was clear. Estimated BPUE was one order of magnitude higher in fall and winter than in spring and summer (Table 2), leading to more bird casualties in this period (547 versus 153, respectively). This was expected, as the Sound is a major wintering area for many migratory birds (Skov, 2011). In terms of proportion, three species made up to more than $90 \%$ of the total observed bycatch: the common eider S. mollissima (58.4\%), the great cormorant P. carbo (19.6\%) and the common guillemot Uria aalge (12.4\%). Except for seagulls (0.4\%), all the birds found drowned in gillnets were diving species. These findings confirm that diving seabirds are generally more vulnerable to bycatch in gillnets than are surface feeding seabirds (Žydelis et al., 2009; 2013). This contrasts with a recent study from Norway, which found that the largest proportion of bird bycatch in the Norwegian Reference Fleet coastal gillnet fishery was a surface-feeding seabird, the Northern fulmar Fulmarus glacialis (Bærum et al., 2019). Moreover, the distribution of bycatch in the Sound showed important disparities between species and a possible clustering for some (Figure 3). Common eider bycatch was registered mostly in shallow waters, whereas pursuit divers such as common guillemots were typically observed farther offshore. This is in line with what is known of the feeding strategies of those species. Common eiders feed principally on molluscs and forage on the seabed. In the Sound, their favourite prey item, the blue mussel Mytilus edulis, is abundant and grows in large aggregations (aka mussel banks). Problematically for these birds, fishers tend to set their nets in and around mussel banks where they expect to find the largest cods. On the contrary, common guillemots can dive farther down to catch the fish they feed on, and they were accordingly often captured in nets set in deeper waters. Conversely, incidental catch of great cormorants, also a pursuit diver, did not seem to be associated with depth or distance to shore. Individuals taken as bycatch may have been specialised in foraging in nets, which would put them at higher risks of entanglement (Bregnballe and Frederiksen, 2006). Furthermore, a differential risk of drowning was observed within two species: the common eider and the great cormorant (Table 3). Common eider vulnerability to bycatch was clearly sex-biased. Males represented almost $70 \%$ of the total catch, but this proportion reflects the male bias in the Baltic population (Ramula et al., 2018). Great cormorant bycatch appeared age-biased (56\% juveniles and immature birds). Bregnballe and Frederiksen (2006) hypothesised that young and less experienced individuals are more at risk of interacting with soaked fishing gears and drown.

These few examples emphasize that deadly seabird-fishery interactions cannot be summarised as a simple overlap between fishing effort distribution and seabird distribution. Complex and speciesspecific relationships exist between birds and fisheries, and depend on many factors including behavioural, operational, environmental or meteorological (Torres et al., 2013; Clay et al., 2019). In the Sound, in the absence of detailed maps of the fishing effort and of the seabird distribution, long term EM monitoring of coastal gillnetters provides insightful data, which helps understanding underlying bird-fisheries interactions. This knowledge is essential to improve and advance both the management of coastal fisheries and the conservation of marine avifauna (Northridge et al., 2017; Le Bot et al., 2018). Besides, understanding the possible impact of fisheries bycatch at population levels requires further investigation. Two of the most affected species in this study, the common eider and the common guillemot, regionally qualify as near threatened on the IUCN Red List, while 
the great cormorant is considered least concerned (IUCN 2019). Moreover, because of the large decline observed since the 1990's, the HELCOM Red List categorises the common eider wintering population as endangered (Kontula and Haldin, 2013). Additionally, fishing effort is not randomly distributed, since skippers normally set their nets in areas where they expect to maximize the catch of their target species. Therefore, bycatch numbers are only relevant in relation to fishing intensity. The literature often reports bycatch rates in gillnet fisheries as the mean number of animals captured per trip, or as the mean number of animals captured per net. Here, EM was utilized to access fine-scale effort data over long periods and to identify fishing grounds and bycatch hotspots precisely. Furthermore, incidental catches are rare events, and authors studying seabird-fisheries interactions often work with datasets containing sporadic bird bycatch. Such data are typically overdispersed (relative to the Poisson assumption), with a high proportion of zeros (i.e. no bycatch in a haul/trip) and localised large counts due to the gregarious behaviour of some species (Sims et al., 2008). As suggested by Bærum et al. (2019), these unpredictable extreme events could considerably bias mean BPUE estimates and lead to exaggeratedly high predictions if used to feed a statistical model. In the present study, 14 fishing trips (corresponding to the $5 \%$ upper quantile) captured more than six birds per trip. To visualize the influence of mass bycatch, BPUE estimates were presented with and without these extreme events (Figure 4 and Figure 5). Moreover, BPUE estimates were also reported both as the number of bird captured per fishing trip $(b p t)$ - as is the case in numerous publications on seabird bycatch in gillnet fisheries (Le Bot et al., 2018) - and as the number of birds per kilometer.hour $(b k h)$. The latter estimates BPUE at haul level by incorporating explanatory operational factors (soak duration and net length). Regardless of the metric, the comparison of Figures 4 and 5 showed that mass bycatch events clearly affect the mean estimator of BPUE: after excluding the $5 \%$ upper quantile, mean yearly estimated bycatch rates dropped by almost a third, and months where extreme bycatch had been observed (especially November) appeared much less peculiar. Therefore, it may be necessary to remove these outliers when building a predictive statistical model to allow the model to converge or at least to calculate reliable estimates. However, with $40 \%$ of all observed bycatch recorded in mass bycatch events, ignoring these will necessarily result in over-optimistic results.

A straightforward solution to overcome the problem of accuracy of bycatch rate estimates is to increase the monitoring effort. However, the cost associated with EM (both implementation and running cost) is often pointed out as a weakness (van Helmond et al., 2019). Consequently, it is tempting to choose to analyse only a randomly selected fraction of the fishing activity. Problematically, bird bycatch events are rare and not randomly distributed. In this study, $40 \%$ of the casualties were recorded in less than $0.2 \%$ of the hauls. As a result, examining a sample of the complete dataset would likely result in inaccurate estimates. Still, compared to alternatives like human observers, EM is generally less biased (no observer effect) and more cost-effective (Michelin et al., 2018). Additionally, self-reporting of bycatch for the vessels equipped with EM could help reduce the number of hauls to analyse and the cost associated with it, as long as quality control procedures are in place. In turn, a dedicated EM programme should aim at evaluating bycatch rates accurately on few representative vessels instead of spreading the monitoring effort on a large portion of the fleet whose activity will be only partially analysed.

Quality EM data requires the full cooperation of the participating fishing vessels. Crewmembers need to comprehend the necessity to keep a clear and unobstructed view for the CCTV cameras, and not withdraw information by switching off the monitoring system. A close collaboration between the fishing industry and scientists, as well as strong incentives (e.g. in the form of additional quotas or days at sea), is necessary to overcome the initial distrust that the fishing community might have toward EM systems (Mangi et al., 2015). Ideally, a monitoring programme should randomly select the fishing vessels to survey. It was not the case here. The sampled vessels were all volunteers, and consequently, they cannot be considered representative of the overall fishing fleet. Besides, regular contacts with the skippers involved in the project may have made them aware of seabird bycatch 
issues. In turn, they may have avoided areas where they believed the risk of incidental catch was high, thus making the estimated BPUE for the sampled gillnetters lower than for the rest of the fleet. However, on small-scale vessels such as the ones in the Sound, catching many birds increases handling time enormously and reduces profitability. Therefore, fishers tend to minimise unwanted catches, avoiding fishing grounds where the possibility of capturing many seabirds is high, even if this means relocating their nets to areas potentially less attractive in terms of catches of target species (Savina, 2018).

In summary, i) bycatch rate estimates were based on a fraction of the total fishing effort of the sampled vessels (Table 4), ii) mass bycatch events were excluded to obtain more reliable mean BPUE estimates (Figure 4 and Figure 5), and iii) participating fishing vessels may have been more attentive to seabird bycatch than average. Consequently, the seabird bycatch rates presented here ought to be considered conservative estimates. Nevertheless, determining such a baseline is essential to unfold the overall impact of gillnets on the seabird populations of the western Baltic Sea.

Establishing long-term electronic monitoring programmes in small-scale gillnet fisheries can provide unique information on incidental captures of seabirds and on the factors associated with bycatch, including fishing effort. Collecting such data is essential in fisheries with a suspected bird bycatch problem. For instance, the lumpsucker gillnet fisheries in the North Atlantic, characterized by long soak times, extensive net length and the use of large meshes, have been reported to capture large numbers of seabirds (Christensen-Dalsgaard et al., 2019). In these fisheries, EM with CCTV could, together with on-board observers, be the most efficient way to collect seabird bycatch data, essential both for fisheries managers to ensure the sustainability of artisanal coastal fisheries and for conservation scientists to tackle seabird populations decline.

\section{Conclusions}

Electronic monitoring with CCTV appears to be a reliable solution for monitoring the bycatch of seabirds in coastal gillnet fisheries, where vessels are usually too small to accommodate an on-board observer. Video monitoring data is accurate enough to identify individuals at species level and for some species to age and sex them. The high precision of the bycatch rates estimates, both spatially and temporally, allows the determination of areas of high risks of bird bycatch, although mean BPUE are arguably underestimated due to the nature of the sampling scheme. More in-depth analysis of the EM data collected for this study will allow determining which operational and non-operational factors influence seabird bycatch in gillnets, which in turn will permit estimating the overall number of bird casualties at fleet level.

\section{Declaration of competing interest}

None.

\section{Acknowledgements}

This work was made possible through project funding from the European Maritime and Fisheries Fund and the Danish Fisheries Agency (grant number 33113-I-16-040), which is gratefully acknowledged. Moreover, the authors wish to thank all three vessels' crewmembers without whom this study would not have been feasible, as well as all the DTU analysts who participated in the auditing of the video monitoring data. Finally, the authors express their gratitude to Anchorlab and Archipelago Marine Research Ltd for their technical support. 
Anonymous, 2019. Annual report from Denmark on the implementation of Council Regulation (EC) No $812 / 2004$.

Bærum, K.M., Anker-Nilssen, T., Christensen-Dalsgaard, S., Fangel, K., Williams, T. and Vølstad, J.H., 2019. Spatial and temporal variations in seabird bycatch: Incidental bycatch in the Norwegian coastal gillnet-fishery. PloS one, 14(3), p.e0212786.

Bellebaum, J., Schirmeister, B., Sonntag, N. and Garthe, S., 2013. Decreasing but still high: bycatch of seabirds in gillnet fisheries along the German Baltic coast. Aquatic Conservation: Marine and Freshwater Ecosystems, 23(2), pp.210-221.

Bregnballe, T. and Frederiksen, M., 2006. Net-entrapment of great cormorants Phalacrocorax carbo sinensis in relation to individual age and population size. Wildlife Biology, 12(2), pp.143-151.

Chen, G., Han, T.X., He, Z., Kays, R. and Forrester, T., 2014, October. Deep convolutional neural network based species recognition for wild animal monitoring. In 2014 IEEE International Conference on Image Processing (ICIP) (pp. 858-862). IEEE.

Christensen-Dalsgaard S., Anker-Nilssen T., Crawford R., Bond A., Sigurðsson G.M., Glemarec G., K.M., 2019. What's the catch with lumpsuckers? A North Atlantic study of seabird bycatch in lumpsucker gillnet fisheries, Biological Conservation, 240, https://doi.org/10.1016/j.biocon.2019.108278

Clay, T.A., Small, C., Tuck, G.N., Pardo, D., Carneiro, A.P., Wood, A.G., Croxall, J.P., Crossin, G.T. and Phillips, R.A., 2019. A comprehensive large-scale assessment of fisheries bycatch risk to threatened seabird populations. Journal of Applied Ecology, 56, pp.1882-1893.

Croxall, J.P., Butchart, S.H., Lascelles, B.E.N., Stattersfield, A.J., Sullivan, B.E.N., Symes, A. and Taylor, P.H.I.L., 2012. Seabird conservation status, threats and priority actions: a global assessment. Bird Conservation International, 22(1), pp.1-34.

Dalskov, J., \& Kindt-Larsen, L., 2009. Final report of Fully Documented Fishery. Charlottenlund: National Institute of Aquatic Resources, Technical University of Denmark. DTU Aqua-rapport, No. 204-09

Dias, M.P., Martin, R., Pearmain, E.J., Burfield, I.J., Small, C., Phillips, R.A., Yates, O., Lascelles, B., Borboroglu, P.G. and Croxall, J.P., 2019. Threats to seabirds: a global assessment. Biological Conservation.

Emery, T.J., Noriega, R., Williams, A.J. and Larcombe, J., 2019. Measuring congruence between electronic monitoring and logbook data in Australian Commonwealth longline and gillnet fisheries. Ocean \& coastal management, 168, pp.307-321.

579 European Commission, 2012. Communication from the Commission to the European Parliament and 580 the Council: Action Plan for reducing incidental catches of seabirds in fishing gears. European 581 Commission, Brussels.

582 European Commission, 2016. Commission Implementing Decision (EU) 2016/1251 of 12 July 2016 583 adopting a multiannual Union programme for the collection, management and use of data in the 584 fisheries and aquaculture sectors for the period 2017-2019 (notified under document $C(2016)$ 4329).

585 European Union, 2009. Directive 2009/147/EC of the European Parliament and of the Council of 30 586 November 2009 on the conservation of wild birds. Official Journal of the European Communities, 20, 587 pp.7-25. 
Hong, S.J., Han, Y., Kim, S.Y., Lee, A.Y. and Kim, G., 2019. Application of Deep-Learning Methods to Bird Detection Using Unmanned Aerial Vehicle Imagery. Sensors, 19(7), p.1651.

ICES, 2018. Report from the Working Group on Bycatch of Protected Species (WGBYC), 1-4 May 2018, Reykjavik, Iceland. ICES CM 2018/ACOM:25. 128 pp.

IUCN, 2019. The IUCN Red List of Threatened Species. Version 2019-2. http://www.iucnredlist.org. (downloaded on 01 November 2019.).

Kindt-Larsen, L., Kirkegaard, E. and Dalskov, J., 2011. Fully documented fishery: a tool to support a catch quota management system. ICES Journal of Marine Science, 68(8), pp.1606-1610.

Kindt-Larsen, L., Larsen, F., Stage, B. and Dalskov, J., 2012a. Final report. Fully documented fishery onboard gillnet vessels > 15 m. Charlottenlund: DTU Aqua. Institut for Akvatiske Ressourcer.

Kindt-Larsen, L., Dalskov, J., Stage, B. and Larsen, F., 2012b. Observing incidental harbour porpoise Phocoena phocoena bycatch by remote electronic monitoring. Endangered Species Research, 19(1), pp.75-83.

Kindt-Larsen, L., Berg, C.W., Tougaard, J., Sørensen, T.K., Geitner, K., Northridge, S., Sveegaard, S. and Larsen, F., 2016. Identification of high-risk areas for harbour porpoise Phocoena phocoena bycatch using remote electronic monitoring and satellite telemetry data. Marine Ecology Progress Series, 555, pp.261-271.

Kontula, T. and Haldin, J., 2013. HELCOM Red List of Baltic Sea species in danger of becoming extinct. Le Bot, T., Lescroël, A., Grémillet, D. and Handling editor: Stephen Votier, 2018. A toolkit to study seabird-fishery interactions. ICES Journal of Marine Science, 75(5), pp.1513-1525.

Lewison, R.L., Crowder, L.B., Wallace, B.P., Moore, J.E., Cox, T., Zydelis, R., McDonald, S., DiMatteo, A., Dunn, D.C., Kot, C.Y. and Bjorkland, R., 2014. Global patterns of marine mammal, seabird, and sea turtle bycatch reveal taxa-specific and cumulative megafauna hotspots. Proceedings of the National Academy of Sciences, 111(14), pp.5271-5276.

Macbeth, W.G., Butcher, P.A., Collins, D., McGrath, S.P., Provost, S.C., Bowling, A.C., Geraghty, P.T. and Peddemors, V.M., 2018. Improving reliability of species identification and logbook catch reporting by commercial fishers in an Australian demersal shark longline fishery. Fisheries Management and Ecology, 25(3), pp.186-202.

Mangi, S.C., Dolder, P.J., Catchpole, T.L., Rodmell, D. and de Rozarieux, N., 2015. Approaches to fully documented fisheries: practical issues and stakeholder perceptions. Fish and Fisheries, 16(3), pp.426-452.

Michelin, M., Elliott, M., Bucher, M., Zimring, M. and Sweeney, M., 2018. Catalyzing the growth of electronic monitoring in fisheries. The Nature Conservancy and California Environmental Associates.

Niemi, J. and Tanttu, J., 2018. Deep Learning Case Study for Automatic Bird Identification. Applied Sciences, 8(11), p.2089.

Northridge, S., Coram, A., Kingston, A. and Crawford, R., 2017. Disentangling the causes of protected-species bycatch in gillnet fisheries. Conservation Biology, 31(3), pp.686-695.

Plet-Hansen, K.S., Bergsson, H. and Ulrich, C., 2019. More data for the money: Improvements in design and cost efficiency of electronic monitoring in the Danish cod catch quota management trial. Fisheries Research, 215, pp.114-122.

Pott, C. and Wiedenfeld, D.A., 2017. Information gaps limit our understanding of seabird bycatch in global fisheries. Biological Conservation, 210, pp.192-204. 
630 Ramula, S., Öst, M., Lindén, A., Karell, P. and Kilpi, M., 2018. Increased male bias in eider ducks can 631 be explained by sex-specific survival of prime-age breeders. PloS one, 13(4), p.e0195415.

632 Savina, E., 2018. Gear technical contributions to an ecosystem approach in the Danish bottom set 633 nets fisheries (PhD thesis). DTU Aqua.

634 Sims, M., Cox, T. and Lewison, R., 2008. Modeling spatial patterns in fisheries bycatch: improving 635 bycatch maps to aid fisheries management. Ecological applications, 18(3), pp.649-661.

636 Skov, H., 2011. Waterbird populations and pressures in the Baltic Sea (Vol. 550). Nordic Council of 637 Ministers.

638 Tasker, M.L., Camphuysen, C.J., Cooper, J., Garthe, S., Montevecchi, W.A. and Blaber, S.J., 2000. The 639 impacts of fishing on marine birds. ICES journal of Marine Science, 57(3), pp.531-547.

640 Torres, L.G., Sagar, P.M., Thompson, D.R. and Phillips, R.A., 2013. Scaling down the analysis of 641 seabird-fishery interactions. Marine Ecology Progress Series, 473, pp.275-289.

642 van Helmond, A.T.M, Mortensen, L.O., Plet-Hansen, K.S., Ulrich C., Needle C.L., Oesterwind D., Kindt643 Larsen L., Catchpole T., Mangi S., Zimmermann C., Olesen H.J., Bailey N., Bergsson H., Dalskov J., 644 Elson J., Hosken M., Peterson L., McElderry H., Ruiz J., Pierre J.P., Dykstra C., Poos J.J., 2019.

645 Electronic monitoring in fisheries: Lessons from global experiences and future opportunities. Fish 646 and Fisheries. https://doi.org/10.1111/faf.12425

647 Žydelis, R., Bellebaum, J., Österblom, H., Vetemaa, M., Schirmeister, B., Stipniece, A., Dagys, M., van 648 Eerden, M. and Garthe, S., 2009. Bycatch in gillnet fisheries-An overlooked threat to waterbird 649 populations. Biological Conservation, 142(7), pp.1269-1281.

650 https://doi.org/10.1016/j.biocon.2009.02.025

651 Žydelis, R., Small, C. and French, G., 2013. The incidental catch of seabirds in gillnet fisheries: A 652 global review. Biological Conservation, 162, pp.76-88. https://doi.org/10.1016/j.biocon.2013.04.002 